\title{
Kierkegaard on the Christian Response to the God who Establishes Kinship with Us in Time
}

ANDREW B. TORRANCE

\section{Introduction}

In Søren Kierkegaard we find a scholar who was concerned with the nature of human existence, and who is often caricatured as the "father of existentialism". Yet Kierkegaard saw himself primarily as a thinker devoted to understanding 'the issue: becoming a Christian'. ${ }^{1}$ Furthermore, he believed that his authorship was inspired by the governance (Styrelse) of the real God. ${ }^{2}$ This was a belief that he

\footnotetext{
${ }^{1}$ Søren Kierkegaard, Søren Kierkegaard Skrifter vol. 16, eds. Niels Jørgen Cappelørn, Joakim Garff, Kette Knudsen, Johnny Kondrup, Alastair McKinnon and Finn Hauberg Mortensen (Copenhagen: Gads Forlag, 1997-2013) (hereafter SKS), 11 / Søren Kierkegaard, The Point of View for My Work as an Author, ed. and trans. Howard V. and Edna H. Hong (Princeton, NJ: Princeton University Press, 1998) (hereafter $P V), 23$.

While this essay accepts Kierkegaard's self-assessment, it should be noted that there is much debate over his claim that his 'whole authorship pertains to Christianity'. Some scholars, including Joakim Garff and Henning Fenger, argue that Kierkegaard's later retrospective outlook on his authorship misremembers (or dishonestly remembers) some of his earlier aesthetic works as serving a much more explicitly Christian purpose than they actually did at the time. (See Henning Fenger, 'Kierkegaard as a Falsifier of History', in Kierkegaard, the Myths and Their Origins (New Haven, CT: Yale University Press, 1980), 1-31; Joakim Garff, Søren Kierkegaard: A Biography, trans. Bruce H. Kirmmse (Princeton, NJ: Princeton University Press, 2005), 550-54; Joakim Garff, 'The Eyes of Argus: The Point of View and Points of View with Respect to Kierkegaard's 'Activity as an Author', trans. Bruce H. Kirmmse, in Kierkegaard: A Critical Reader, ed. Jonathan Rée and Jane Chamberlain (Oxford: Blackwell, 1998)). Moreover, Alastair Hannay claims that Kierkegaard 'nurture[d] a lifelong ambivalence towards Christianity which allowed him to hold it at a distance'. (Alastair Hannay, Kierkegaard: A Biography (Cambridge: Cambridge University Press, 2001), 39). While this article will not directly engage with the positions of Garff and Fenger, it will hopefully serve to offer a challenge to Hannay's claim. For a critique of Garff's position, see Sylvia Walsh, 'Reading Kierkegaard with Kierkegaard against Garff,' Søren Kierkegaard Newsletter 38 (1999), 4-8; and Garff's response to Walsh in 'Rereading Oneself,' Søren Kierkegaard Newsletter 38 (1999), 9-14. For a superb analysis of this issue, and a helpful critique of deconstructionist readings of Kierkegaard, see Mark Tietjen's Kierkegaard, Communication, and Virtue (Bloomington, IN: Indiana University Press, 2013), 61-85.

${ }^{2}$ Kierkegaard writes, '[God's] [g] overnance has supported me indescribably much' (SKS 21, 233 [NB9:56] / Kierkegaard's Journals and Notebooks, vol. 5, eds. Niels Jørgen Cappelørn, Alastair Hannay, David Kangas, Bruce H. Kirmmse, George Pattison, Vanessa Rumble, and K. Brian Söderquist (Princeton, NJ: Princeton University Press) (hereafter $K J N$ ), 243; see also Lee Barrett's extremely helpful chapter, 'Kierkegaard's Authorship and the Paradox of Andrew B. Torrance University of St Andrews, School of Divinity, St Mary's College, South Street, St Andrews Fife KY16 9JU, UK Email: abt3@st-andrews.ac.uk
} 
carried into his work: 'it was religiously my duty that my existing and my existing as an author express the truth, which I had daily perceived and ascertained - that there is a God.' ${ }^{3}$

That having been said, there are areas in his thought that seem to disregard the external reality of God and his continuing engagement with history. ${ }^{4}$ When reading through these sections, there is room to misinterpret Kierkegaard's vision of Christianity in terms that fail to distinguish it decisively from immanent accounts of Christianity: Christianity that is grounded in a person's subjective commitment to her own understanding of what Christianity is - an understanding that is possessed within the mind of the human believer and which can be held in abstraction from the gracious activity of the divine subject. On this view, Christianity, above all else, concerns an individual's belief in her own perception of God, informed, for example, by her own reflection on Scripture. Under these circumstances, the Christian is not primarily oriented toward the eternal truth (God) that always transcends her existence and which can only be received derivatively from the divine-human mediator of that truth. Instead, the 'essence' of the Christian task, as Clare Carlisle contends, primarily involves a passionate and active relationship to a person's own idea of its absolute telos: a relationship in which the Christian actively repeats in her existence that which she professes in her relationship with God. ${ }^{5}$ In these terms, the decisive becoming of the Christian life concerns a process of self-transformation that takes place in response to the truth that is given in

Divine and Human Agencies' in International Kierkegaard Commentary on The Point of View, ed. Robert L. Perkins (Macon, GA: Mercer University Press, 2010), 65-75).

${ }^{3}$ SKS 16, 51n. / PV, $72 \mathrm{n}$.

${ }^{4}$ This is particularly evident in Kierkegaard's earlier pseudonymous works, which, as I note in footnote 19 below, should not be attributed to Kierkegaard. That said, a disregard for the external reality of God is also evident in some of Kierkegaard's own signed works, particularly in those discourses that Howard and Edna Hong gathered together in Eighteen Upbuilding Discourses. Consequently, as I note in footnote 52 below, Kierkegaard's pseudonym, Johannes Climacus did not consider these discourses to be decisively Christian.

${ }^{5}$ Clare Carlisle, 'Climacus on the task of becoming a Christian' in Concluding Unscientific Postscript: A Critical Guide, ed. Rick Furtak (Cambridge: Cambridge University Press, 2010), 185. Here, Carlisle also contends that 'Kierkegaard's analysis of the Christian task in the Postscript is characterized by an absolute refusal... to think beyond existence.' (185). 
revelation - a truth which, as George Pattison writes, 'is essentially and ontologically conformable to the structures of thinking, self-conscious human life. ${ }^{6}$

When readers fail to appreciate the total extent of the distinction between Christianity and immanent religiousness, Kierkegaard becomes tied to a religiosity that primarily sees the incarnate God as a means for humanity to receive the truth rather than the one who is the truth-for-humanity. On this view, it is a person's inward transformation into faith that is the ground of her relationship with God, rather than a person's relationship with God that is the ground for her life of faith. As a result, the message that Christ embodies is seen to be more fundamental than the living person of Christ.

How might Jesus Christ be interpreted in this way? Steven Emmanuel interprets Jesus Christ as the one who 'represents the ideal embodiment of the doctrine (the Word revealed in the flesh)' ${ }^{7}$ Also, M. Jamie Ferreira describes Christ (or 'the teacher') as the one who 'exemplifies or embodies a paradoxical message (the message of unlikeness and likeness, of "absolute difference" and "absolute equality")'. In both of these examples, the emphasis is placed on the 'doctrine' or 'message' that Christ embodies. By so doing, both statements risk echoing Hegel's emphasis on the incarnation as the event which exhibits and communicates the higher unity, or absolute reconciliation, of divine and human nature. For Kierkegaard, however, there is something much more radical and decisive that takes place in the event of the incarnation. The incarnation creates a union between God and a particular human being that holds no reality until God becomes human in

\footnotetext{
${ }^{6}$ George Pattison, Kierkegaard and the Theology of the Nineteenth Century: The Paradox and the Point of Contact (Oxford: Oxford University Press, 2012), 89. For further critical engagement with this point, see my article: 'Beyond Existentialism: Kierkegaard on the Human Relationship with the God Who is Wholly Other' in International Journal of Systematic Theology 16 no. 3 (2014): 303-5.

${ }^{7}$ Steven Emmanuel, Kierkegaard and the Concept of Revelation (Albany, NY: State University of New York Press, 1996), 105.

${ }^{8}$ M. Jamie Ferreira, Transforming Vision (Oxford: Clarendon Press, 1991), 97.
} 
Christ and continues to have no reality apart from the person of Jesus Christ. ${ }^{9}$ This means that human thought cannot abstract the essential truth of the incarnation from the person of Christ and appropriate it into a human message about the unity of God and humanity. It also means that while the absolute paradox of the incarnation was logically possible, to the extent that God could create it, the union that Jesus Christ establishes was not actual until the event of its happening.

What does this imply? Kierkegaard is emphatic that individuals cannot mediate the truth of Christianity to themselves in and through their own autonomous understanding - their own absolutely different understanding. Individuals cannot relate to the essential truth of Christianity by simply reflecting on some (scripturally, doctrinally, or otherwise-informed) notion of Christianity. The essential truth of Christianity is not simply "a truth" that needs to be recollected (i.e. a comprehensible idea of God or the God-human). Furthermore, the Christian truth is not simply the paradoxical idea of unity between eternality and temporality (i.e. an incomprehensible idea that needs to be embraced against the understanding). The essential truth of Christianity is the personal reality of the living God who enters into time as a particular human being and thereby establishes a totally unique kinship (Slcegtskab) between God and humanity: that is, a relationship in which God relates to human beings by sharing with them in their flesh and blood (Heb. 2:14).$^{10}$ It is only in and through the eternal-historical person of Jesus Christ that God positively mediates the eternal truth of who God is to humanity. Kierkegaard writes,

\footnotetext{
${ }^{9}$ Indeed, there is a sense in which the God-human union (Eenhed), which is created in the incarnation, is 'something new for God.' (Paul Sponheim, 'Relational Transcendence in Divine Agency', in International Kierkegaard Commentary: Practice in Christianity, ed. Robert L. Perkins (Macon, GA: Mercer University Press, 2004), 53.) ${ }^{10}$ This description of kinship corresponds to Kierkegaard's account of the incarnate God's relationship to us in his discourse on the High Priest (Heb. 4:25): 'We have not a high priest who is unable to have sympathy with our weaknesses, but one who has been tested in all things in the same way, yet without sin.' (SKS 11, 251-59 / Without Authority, ed. and trans. Howard V. and Edna H. Hong (Princeton, NJ: Princeton University Press, 1997), 113-24). That said, Kierkegaard does not directly refer to the term 'kinship' (or Slagtskab) in this discourse.
} 
A Mediator is necessary for me, among other reasons, simply to make me aware that it is God with whom, as we say, I have the honor of speaking; otherwise a man can easily live on in the indolent conceit that he is talking with God, whereas he is only talking with himself. ${ }^{11}$

In Jesus Christ, the living God reveals himself to the world in a way that makes it possible for human beings to share in an interpersonal relationship with God. Within this relationship a person is nurtured and maintained in her faithfulness by the grace of God: she actively responds to God because God actively involves himself in her life, governing her and transforming her into a person who can live according to God's (incarnate) truth.

What we find in Kierkegaard's Christian thought is a twofold account of how God relates to persons in time. First, God creates an eternal-historical union with human beings in and through the person of Jesus Christ. By assuming our humanity, God relates to persons in the temporality of their human situation. ${ }^{12}$ Second, following the crucifixion, the risen and ascended Christ continues to relate to persons spiritually: that is, by way of a gracious activity and presence that comes to us from beyond our physical existence but yet maintains the kinship that was created in the incarnation. Using the terminology of Philosophical Fragments, Jesus Christ continues to encounter persons in particular moments in time in a way that enables a form of contemporaneity with persons

\footnotetext{
${ }^{11}$ SKS 24, 237 [NB24:13] / Journals and Papers, vol. 2, ed. and trans. Howard V. and Edna H. Hong (Bloomington, IN: Indiana University Press, 1967-78) (hereafter $J P$ ), 1424 (emphasis and emboldening original).

${ }^{12}$ This notion is pondered further by Climacus in his tale of the king and the maiden, see SKS 4, 233-42 / Kierkegaard, Philosophical Fragments, ed. and trans. Howard V. and Edna H. Hong (Princeton, NJ: Princeton University Press, 1985) (hereafter $P F$ ), 26-36. The limited focus of this article, however, does not allow for detailed discussion of this issue. For further reflection, see David Law, Kierkegaard's Kenotic Christology (Oxford: Oxford University Press, 2013).
} 
who did not have the opportunity to encounter Jesus Christ during his earthly life. ${ }^{13}$ Kierkegaard hesitates to say too much more about precisely how God encounters persons in history. Since it is miraculous, the details lie beyond the scope of human understanding and can only be known by the mind of God. Nonetheless, what is clear, for him, is that the Christian life rests on the fact that God actively relates to persons in the midst of this historical world. In short, he presents this active relationship as: (1) grounded in the kinship that God establishes with the world in and through the incarnation, and (2) maintained by the ascended God-human's spiritual activity. ${ }^{14}$

By participating in an interactive relationship with God, a person receives the faith to make sense of her life in such a way that any apparent absurdity surrounding the incarnation ceases to be perceived as such.

When the believer has faith, the absurd is not the absurd-faith transforms it, but in every weak moment it is again more or less absurd to him. The passion of faith is the only thing which masters the absurd - if not, then faith is not faith in the strictest sense, but a kind of knowledge. ${ }^{15}$

\footnotetext{
${ }^{13}$ It would be helpful to enter into an extended discussion of the significance of Philosophical Fragments on this issue. Space, however, does not allow for such discussion and such work has already been done elsewhere by others in great detail. I would particularly recommend Murray Rae, Kierkegaard's Vision of the Incarnation (Oxford: Oxford University Press, 1997).

${ }^{14}$ The clarity of Kierkegaard's thinking here would have benefited from a much more robust pneumatology. One suspects that the reason he did not provide more explicit consideration of the work of the Holy Spirit reflected his resistance to the Hegelian emphasis on the divine spirit (Geist), and the way it was used to endorse a unity between God and human immanence. That said, Kierkegaard does discuss the importance of the work of the Holy Spirit. See, for example, his For Self-Examination / Judge for Yourself!, trans. and ed. Howard and Edna Hong (Princeton, NJ: Princeton University Press, 1990), 71-87. For further analysis of Kierkegaard's pneumatology, see my article: 'Beyond Existentialism', 308-12.

${ }^{15}$ Søren Kierkegaard Papirer, vols. I-XVI (second expanded edition), ed. Niels Thulstrup, vols. XII to XIII supplementary volumes, ed. Niels Thulstrup (Copenhagen: Gylendal, 1968-78) (hereafter Pap.), X-6 B 79 / JP 1, 10.
} 
This passage is easily misunderstood. So it is important to be clear about what precisely Kierkegaard is saying here. When the absurd ceases to be the absurd, this is not because a person suddenly receives an intellectual capacity to work out the rationale of the incarnation. Nor is it because a person humbly and fideistically resolves, in and of herself, to embrace the absolute paradox as a paradox that she cannot comprehend. Rather, it is because God draws her into a 'friendship' in which she finds the 'courage' and 'enthusiasm' to embrace that which she would otherwise have perceived to be an absurdity, given her preconceived notions of what God can and cannot do. ${ }^{16}$ In this friendship, a person becomes so consumed by a love for God that she becomes 'blind' to any apparent intellectual difficulties that are involved in recognising the possibility of a relationship between 'two qualities so unlike as God and man'-a relationship, moreover, that is mediated by the God-man. ${ }^{17}$ This does not mean that she becomes blind to the truth. Rather, she is awakened by the truth to the truth. As the one who is the truth, the God-human makes sense of her existence despite the fact that she cannot unravel the mystery of the incarnation. As this happens, the reality of Jesus Christ calls into question any brazen concern for intellectual mastery.

In sum, Jesus Christ does not encounter persons as a puzzle to be solved. But neither does he encounter persons as an abstract reality to be blindly embraced. Rather, he confronts persons as the one who calls them to discipleship. Jesus offers an invitation for persons to come to love and follow him. And he does this as the light of the world who bestows truth upon human knowing. When a person stands before God, awakened by his truth, she subordinates herself, not simply to a paradox that immediately seems unfathomable but to the living God who, by establishing kinship with human persons in time, lovingly draws her to himself and into the truth that he is in himself.

\footnotetext{
${ }^{16}$ Pap., X-6 B $79 / J P 1,10$.

${ }^{17}$ Pap., X-6 B 79 / JP 1, 10.
} 
There is no immanental underlying kinship [Sloegtskab] between the temporal and the eternal, because the eternal itself has entered into time and wants to establish kinship [Sloegtskabet] there. ${ }^{18}$

In view of this interpretation of Kierkegaard's Christian vision, this essay will contend that Kierkegaard's Christian thought needs to be associated with a Christian realism: a realism that prioritizes the reality of the living God who personally involves himself with creation, in history, and does so over against independent human ideas of God. To argue this case, I shall demonstrate that Kierkegaard's account of the Christian faith is first and foremost grounded in a person's outward relationship with the (mind-independent) reality of God who established kinship with us in time. To establish this, I shall offer a close reading of Concluding Unscientific Postscript, focusing on the ways in which Kierkegaard's non-Christian pseudonym, Johannes Climacus, ${ }^{19}$ distinguishes Christianity from immanent forms of religiousness. I shall then consider, albeit very briefly, two ways in which Kierkegaard employed this position in his own authorship, looking specifically at his understanding of sin-consciousness and repentance.

The reason for turning to Climacus' Postscript to better understand Kierkegaard's own theological position is because of a point that Kierkegaard makes in his spiritual autobiography, The Point of View for My Work as an Author. Here, Kierkegaard asserts that Concluding Unscientific Postscript 'constitutes the turning point in my entire work as an author, inasmuch as it poses the

\footnotetext{
${ }^{18}$ SKS 7, 520 / Concluding Unscientific Postscript to Philosophical Fragments, ed. and trans. Howard V. and Edna H. Hong (Princeton, NJ: Princeton University Press, 1992) (hereafter CUP), 573.

${ }^{19}$ Johannes Climacus describes himself as an 'outsider' to the Christian faith. (SKS 7, 26 / CUP, 16). In this essay, I respect Kierkegaard's wish 'that anyone who wants to quote something from the pseudonyms will not attribute that quotation to me.' (Pap., X-6 B 145 / JP 6, 6786).
} 
issue: becoming a Christian. ${ }^{, 20}$ At the heart of Postscript, we find Climacus turning to contemplate what it means (for the Christian) to be human before the reality of God-a focus that went on to characterise Kierkegaard's later religious authorship. Critical to this turn is the one whom Climacus calls "the god in time" (Gud i Tiden). ${ }^{21}$

\section{Kierkegaard and Climacus}

Before turning to Postscript, it will be helpful to say a bit more about the relationship between the author Kierkegaard and his pseudonym Climacus. As mentioned above, Climacus saw himself as an outsider to the Christian faith; as such, he was someone who could not yet recognise the truth of Christianity for himself. But, he also saw himself as someone who was interested in the question, 'How can I, Johannes Climacus, share in the happiness that Christianity promises?'. ${ }^{22}$ By exploring this question, he was able to develop an outsider's account of what Christianity is. However, he was more than merely an outsider. He was an observer who thought about Christianity as a dialectician, a humourist, and a psychologist. As such, he was the kind of thinker who could have settled into the kind of ivory tower conversations that were taking place amongst the rationalistic and bourgeois Christians in Denmark. Yet, unlike many of the rationalists, Climacus was not stubbornly committed to developing a detached account of Christianity. Rather, he was genuinely interested in the happiness (or 'happy passion') that Christianity promises. ${ }^{23}$ This enabled him to provide a more

\footnotetext{
${ }^{20} S K S 16,44$ / PV, 63.

${ }^{21}$ The unusual way of referring to 'God in time' as 'the god in time' (with the definite article and a lower case " $\mathrm{g}$ ") is used in the Hongs' translation of Concluding Unscientific Postscript in keeping with Climacus' attempt to consider Christianity from a Socratic or idealist perspective (see below). (For Howard Hong's explanation of this translation, see $P F$, p. 278 n. 13). Accordingly, when referring to Climacus' references to God in time, I refer to "the god in time". However, at a couple of points, when taking the discussion beyond Climacus' writings, I shall refer to God in time. ${ }^{22}$ SKS 7, 26 / CUP, 17.

${ }^{23}$ In Philosophical Fragments, Climacus describes faith (which he goes on to associate with the faith of the Christian in Postscript) as a 'happy passion' (SKS 4, 257, 261 / PF, 54, 59).
} 
attentive account of what Christianity is, evident in his superb understanding of the passionate nature of Christianity. Nonetheless, his deep appreciation for the passionate nature of Christianity could not itself stop him from being an outsider.

Kierkegaard's relation to Christianity was quite different. By having come to faith, he saw himself as reconciled with God, and saw himself as someone who, to some extent, knew what it meant to be a Christian. According to a Climacean account of Christianity, this is because he had become subject to a decisive moment in history in which the eternal God had delivered him from an existence in untruth into an existence in truth. In accordance with his particular Christian commitment, Kierkegaard's own signed writings did not seek to keep up appearances with Denmark's highbrow Christianity. Rather, they were primarily devoted to "upbuilding" (Opbyggelse) his readers in their lives of Christian discipleship.

At the same time, Kierkegaard also sought to challenge the ways in which the cultural and intellectual elite in Denmark were distorting "Christianity" to fit to their own particular interests and agendas. According to their brand of "Christianity", the truth of the Christian faith was something to be discovered by way of a scholarly devotion to Christian doctrine and teaching. In order to challenge this perception, Kierkegaard created a character who was able to speak to the rationalists on their own terms: Johannes Climacus. What the non-Christian Climacus was able to do (and which Kierkegaard could not) was stand back as an observer of Christianity and thereby offer a more detached analysis of what Christianity is. Nonetheless, as someone who could grasp what Kierkegaard was seeking to achieve, and as someone who was sensitive to the passionate nature of Christianity, Climacus was also able to question the implications of interpreting the truth of Christianity in purely intellectual terms: or, more specifically, from a Socratic or idealist perspective. Climacus does this by pointing to the coherence of an alternative way of understanding 
the truth of Christianity_ one that contrasted with a Socratic or idealist approach. What becomes apparent is that this alternative bears a much more striking resemblance to orthodox Christianity than its 'Socratic' alternative. ${ }^{24}$ By using Climacus to point this out, Kierkegaard was able to challenge his readers and help them to recognize the problematic nature of their approach.

It is important to be clear, however, that Kierkegaard was not under the impression that he could use Climacus to translate the truth of Christianity into the language of the rationalists. Nor did he believe that the grace of God somehow depended upon his particular communication skills. By speaking to the rationalists in their own terms, through the voice of Climacus, Kierkegaard was able to question them in ways that penetrated their speculative strategies and challenged them to rethink how they were relating to Christianity. He was, in effect, playing them at their own game: by exposing the limits of their position via their own methods.

In this way, he questioned their unyielding confidence in the powers of immanent reason and opened the doors to the suggestion that the truth is to be found through a relationship with God, who is beyond the scope of unredeemed human reason-God, who cannot be conjured up within the mind's own resources, that is, by philosophical argumentation or analysis. By presenting them with this alternative, Kierkegaard and Climacus were able to draw attention to the essential supposition of the Gospel, namely, that it is God's Son who makes God known (John 1:18). For Kierkegaard, God is known in and through the reconciliation of our minds which takes place in Jesus Christ who is the way, the truth and the life - and who thus constitutes, in himself, the condition whereby we are brought into relationship with the truth. This involves the reorientation of our focus back to the one who alone can draw persons into the Christian life.

\footnotetext{
${ }^{24}$ This account of what Kierkegaard and Climacus are doing is highly summarized and simplified. As such, I have overlooked a number of important nuances. For a much richer discussion on this area, I would, again, highly recommend Murray Rae's Kierkegaard's Vision of the Incarnation.
} 
By using Climacus to converse with the intellectuals of his day, Kierkegaard translated the "what" of Christianity into a message that related (albeit challengingly) to the subjective mindset of a particular people. Again, however, he did so with an acute awareness that his "translation" of the Gospel could only go so far. He did not for a moment believe that he could employ his intellectual powers of persuasion to bring people closer to God and enable them to become Christian. He could not translate the presence of God to people, and so could not draw persons into the spiritual relationship with God that is decisive for coming to faith. He sought instead to undercut the intellectual foundations that were strengthening resistance to the possibility that the truth is to be found through a relationship with God who is external to us. In so doing, he created an opportunity to focus again on the revelation that alone defines what Christianity is.

Kierkegaard's concern to shift the focus to God's self-revelation in Jesus Christ is central to what Climacus is doing in Concluding Unscientific Postscript, particularly when it comes to his distinguishing Christianity from immanent forms of religiousness. As Kierkegaard seeks to show through the writings of Climacus, there is an absolute difference between human ideas of Jesus Christ and the divine-human reality of Jesus Christ: the latter is united with God himself, the former is not. For this reason, the Christian faith cannot be maintained without a relationship with Jesus Christ. If a person forgets this, she will lose sight of her need for grace and will start (consciously or unconsciously) looking to herself for upbuilding. Unfaithfully, she will turn inward to her own christology rather than to the reality of Jesus Christ. Consequently, she will become lost for the simple reason that, for Kierkegaard, it is not theology that leads a person to God but 'the Mediator': it is 'Christ who leads us to God... by means of the Spirit'. ${ }^{25}$

\footnotetext{
${ }^{25}$ SKS 25, 140-41 [NB27:23] / JP 2, 1432. Notably, Kierkegaard affirms in this journal entry that a relationship with God begins with the Father who draws us to himself. He writes, 'it is not the Spirit who leads to the Son and the Son
} 
By recognising Kierkegaard's emphasis on this point, the theological and philosophical world is required to rethink what it means to caricature Kierkegaard as the "father of existentialism". Moreover, as this essay will seek to demonstrate, it is not only Kierkegaard's later more robustly theological works that call for a change in this prevailing perception. This call is also prompted by Concluding Unscientific Postscript, a work that has tended to further the perception of Kierkegaard as a primarily "existentialist" thinker, and thereby compromise his reception as an orthodox Christian thinker - a thinker whose vision of Christianity is much more theocentric and Christocentric than it is anthropocentric.

\section{Immanent Religiousness and Christianity}

Throughout the vast majority of Postscript, we are given an account of religiousness that concerns the individual's pathos-filled relation to an eternal happiness. This religiousness revolves around an individual's infinite interest in the god (Guden) and the eternal. Towards the end of Postscript, Climacus identifies this category of religiousness as immanent religiousness, immediate religiousness or religiousness A. While this category of religiousness stresses humanity's absolute alienation from God and the eternal, it also recognises the possibility of a person being able to relate to God by virtue of her own immanent capacities, for example, through a consciousness of guilt. In this respect, Climacus contends, immanent religiousness is qualitatively distinct from the religiousness of Christianity, which denies the possibility of a person being able to relate personally to God by way of her own immanent capacities. ${ }^{26}$ This, however, is a bold contention that needs careful qualification. It is imperative, therefore, that we examine the nature of this distinction

who leads to the Father; no, it is the Father who directs to the Son, the Son who directs to the Spirit, and not until then is it the Spirit who leads to the Son and the Son who leads to the Father.'

${ }^{26}$ See $S K S$ 7, 528 / CUP, 579-80. 
closely_-given, not least, Kierkegaard's description of Postscript as the turning point in his whole authorship. Climacus writes,

The religiousness that has been discussed up until now and that for the sake of brevity will from now on be termed Religiousness A is not the specifically Christian religiousness. $^{27}$

Before turning to consider the precise nature of this distinction, it should be noted that Climacus and Kierkegaard are very happy to acknowledge similarities between immanent and Christian religiousness. Prior to the above statement, there are a number of passages in which Climacus quite plainly refers to Christianity. ${ }^{28}$ This is not because he is being inconsistent. Rather, it is because, up until this point, his references to Christianity have focused on a person's existential commitment to her own idea of what Christianity is. ${ }^{29}$ Clearly, both Kierkegaard and Climacus

\footnotetext{
${ }^{27}$ SKS 7, 505 / CUP, 555.

${ }^{28}$ In these references Climacus goes so far as to refer to Christianity in terms of faith in the 'paradox' (SKS 7, 104, 193, 195, 200, 209, 212, 267, 295, 323, 332-3, 483-4 / CUP, 105, 209-10, 213-4, 220, 230, 233, 293-4, 323-4, 353-4, 364, 532), he talks about the untruth in terms of 'sin' ( $S K S$ 7, 191-2, 323 / CUP, 208, 353-4), and, even more specifically, he mentions the 'god' or 'eternal truth' coming to existence 'in time' (SKS 7, 192-3, 195, 323 / CUP, 209, 213, 353-4). Although these Christian facts can be taken as references to Christianity, as we shall see, they can only be taken as decisively Christian if they inhere in and are derived from the 'something historical' upon which the Christian's eternal happiness is based in truth $(S K S$ 7, 336-7 / CUP, 369). The reason for this is that they also constitute ideas that can be imaginatively constructed and related to in untruth. For Climacus, Christian concepts are not, in and of themselves, essentially Christian (which is why he did not describe his imaginative construction in Fragments as 'Christianity'). (See $S K S$ 7, 330 / CUP, 361-2). As such, when Climacus puts forward an idea about what is essentially Christian ('that an eternal happiness is decided in time in relation to something historical'), this idea is not in itself essentially Christian because, quite simply, the idea itself cannot be the 'something historical' that is decisive for the Christian faith. In short, the decisively Christian cannot be derived from universal ideas about its substance. The Christian faith does not primarily concern a particular individual's infinite interest in God, but concerns God himself reconciling particular individuals into faith.

${ }^{29}$ Accordingly, I would argue that it is an overstatement for Ingolf Dalferth to affirm that 'the argument in the Postscript depends from the first to the last page on the priority of God's creative grace over our ways of receiving it'. (Ingolf Dalferth, 'Becoming a Christian according to the Postscript: Kierkegaard's Christian Hermeneutics of existence' in Kierkegaard Studies Yearbook 2005, eds. N.J. Cappelørn and H. Deuser (Berlin and New York: Walter de Gruyter, 2005), 280).
} 
recognise that the Christian life will involve a person's subjective existence: her passionate commitments, her self-understanding and her own conception of God. And, indeed, both of them devote serious attention to the way in which a person's subjective existence is involved in the process of becoming a Christian. ${ }^{30}$ However, as we have also seen, and as we shall continue to see, they are also clear that becoming a Christian involves much more than existential transformation. A person cannot become a Christian without such transformation. But this transformation cannot occur (in a decisively Christian way) without a person participating in the relationship with God that makes it possible. The problem, however, is that Kierkegaard and Climacus do not always emphasise this point clearly enough. For example, it is only towards the end of Postscript that Climacus clarifies the significance of this distinction. This means that he makes it easy for readers to interpret his vision of Christian religiousness (B) in terms that do not decisively distinguish it from immanent forms of religiousness (A).

What interpretations of Climacus am I concerned about? To provide a couple of examples, M. Jamie Ferreira contends that a person's transition into Religiousness B involves the transforming and deepening of a person's original existence. This transformation, she writes, 'is a function of

\footnotetext{
${ }^{30}$ Indeed, Climacus writes, 'Religiousness A must first be present in the individual before there can be any consideration of becoming aware of the dialectical B. When the individual in the most decisive expression of existential pathos relates himself to an eternal happiness, then there can be consideration of becoming aware of how the dialectical in second place (secundo loco) thrusts him down into the pathos of the absurd. Thus it is evident how foolish it is if a person without pathos wants to relate himself to the essentially Christian, because before there can be any question at all of simply being in the situation of becoming aware of it one must first of all exist in religiousness A.' (SKS 7, 505-6 / CUP, 556-7.) If a person is to become a Christian, on Climacus' account, she cannot merely study Christianity as an objective observer. She must become personally interested in God. She must give him the kind of attention that we find in the pathos-filled subjectivity of Religiousness A: she must humbly approach him as God, before whom she has nothing to offer except her need for him. Simply doing this, however, will not itself bring a person any closer to the true God. But Climacus does suggest that this move can provide the 'impetus' for God then, in second place, to deliver that person into the Christian faith. (SKS 7, 508-9 / CUP, 559-60) '[T] he god [Guden] rescues from delusion the person who in quiet inwardness and honest before God is concerned for himself; even though he is ever so simple, the god leads him in the suffering of inwardness to the truth.' (SKS 7, 559 / CUP, 615). Again, therefore, as I am arguing, it is only by encountering God, in his active presence, that a person can become drawn to know God in truth.
} 
absolute engagement with history. ${ }^{31}$ God provides the world with a qualitatively specific revelation of sin and forgiveness that is then able to inform a person's immanent relation to an eternal happiness, giving it a qualitatively new content. ${ }^{32}$ Another example is evident in Roe Fremstedal's statement that the 'transition from immanent religiousness to transcendent religiousness', in Postscript, is 'a transition from presuppositions we possess to presuppositions that have to be

\footnotetext{
${ }^{31}$ M. Jamie Ferreira, 'The "Socratic secret" - The postscript to the Philosophical Crumbs', in Rick Furtak, ed.
} Concluding Unscientific Postscript: A Critical Guide (Cambridge: Cambridge University Press, 2010), 21-2. To put this quote in context, Ferreira argues in this chapter that, in Postscript, the Socratic is not presented as an alternative to the Christian faith (as it was in Philosophical Fragments), but a form of subjectivity that continues to operate in unison with a person's Christian faith. (Ferreira, 'The "Socratic secret", 15).

Religiousness A, she interprets, is not merely a leaping off point but a stage of existence that continues to play an active role in a person's Christian faith. ("The "Socratic secret", 18). She supports this with Climacus' affirmation that 'every Christian has pathos as in religiousness A'. (SKS 7, / CUP, 582). Furthermore, she also takes Climacus' description of Christian pathos as a 'sharpening pathos' to imply that, in conversion, 'the original pathos is not annihilated. (SKS 7, / CUP, 582; 'The "Socratic secret", 21-22). In light of these and a few other references, she notes that the Christian faith does not require 'a break with human existing, but an accentuation of human existing.' ('The "Socratic secret", 21). Human existence is transformed, heightened and deepened rather than replaced. ("The "Socratic secret"', 19-21). Concluding her discussion, she remarks, 'Climacus' whole motivation was to reawaken people who had forgotten "what it is to live as a human being"- surely, we are not asked to forget that when we become Christian.' ("The "Socratic secret", 22-23).

There are many respects in which I am happy to agree with Ferreira's argument. Climacus does indeed provide a more existential account of Christianity in Postscript than he does in Fragments. By so doing, he sought to challenge the lacklustre "Christianity" of Christendom and stress that 'Being a Christian is defined not by the "what" of Christianity but by the "how" of the Christian.' (SKS 7, 554 / CUP, 610). This meant not only emphasising the grace of God in the Christian life but also stressing that the Christian must strive to live in a way that takes her relationship with God seriously. The Christian must approach God with the existential pathos of Religiousness A: she must interpret her relationship with God as her eternal happiness, must commit her life to worshipping God and do so with an understanding that she is nothing before God. The Christian must think about what it means to be a Christian and struggle to act accordingly. And when she does so, it is not simply the grace of God within her. There is an extent to which her struggle to obey God arises with her own immanent struggle to obey God; there is an extent to which her Christian understanding of God arises with her own immanent understanding of God; and there is an extent to which her Christian passion for God arises with her own immanent passion for God. To become a Christian, for Climacus, a person needs to grapple with the call of Christianity to die to the world and die to the self. By drawing on the importance of the Christian taking her relationship with God seriously (with the pathos of Religiousness A), Climacus does not, however, as I argue here, set aside the irreconcilable differences between Religiousness A and Christianity. As we shall see, Climacus is adamant that whereas Religiousness A is conditioned by a person's own inward deepening in relation to an eternal happiness, Christianity is based upon the 'God in time as an individual human being' who, as 'something outside himself', qualifies a person's eternal happiness 'more specifically'. (SKS 7, 510, 505 / CUP, 561n., $556)$.

Ferreira does not deny a qualitative discontinuity between A and B in Postscript. ('The "Socratic secret"', 23). My concern, however, is that she neglects the decisiveness of God's historical actuality for Christian existence: that the point of departure for the Christian existence is a historical relationship with the real God in time. In her reading, it appears that a person's transition into Religiousness B involves the transforming and deepening of a person's original existence. God provides the world with a qualitatively specific revelation of sin and forgiveness that is then able to inform a person's immanent relation to an eternal happiness, giving it a qualitatively new content. ("The "Socratic secret", 22.)

${ }^{32}$ Ferreira, "The "Socratic secret", 22. 
revealed [sic] ${ }^{33}$ There is much to be said for these two readings. For example, it is entirely appropriate to suggest that becoming a Christian requires a person to embrace a new set of presuppositions. At the same time, as I shall argue, it is not primarily a new set of beliefs in revealed propositions that decisively distinguishes immanent from transcendent religiousness.

For Climacus, the Christian (who embraces transcendent religiousness) does not merely relate to God by committing herself to a divine teaching that was revealed in or by Jesus Christ: a teaching that has been bestowed upon creation history by the grace of God. Rather, she participates in an interpersonal relationship with the living God. So, no matter how much a person might know about revelation (as it is recorded in the Gospels, for example), and no matter how much a person might be committed to this message, if she is not subject to the witness of an entirely new spiritual activity, ${ }^{34}$ and is not upheld by the intervening power of the god in time, then she cannot become decisively Christian. '[T]he appearance of the god in time', Climacus writes, 'prevents the individual from relating himself backward to the eternal, since he now moves forward in order to become eternal in time through the relation to the god in time. ${ }^{35}$ As such, the god in time does not merely pass on new information about a person's immanent relation to the eternal but enters into the world as the 'by-nature eternal' one in and through whom a person can relate to God. ${ }^{36}$ Again, therefore, it is not merely a new set of beliefs that distinguishes transcendent religiousness from immanent religiousness, but the qualitatively new way in which a person relates to God. The Christian relates to the eternal truth by participating in an ongoing relationship with the god in time - a relationship that is facilitated through God's sustained and gracious self-giving. In this account, it is not a person's infinite interest in God's historical revelation that is decisive, but God's

\footnotetext{
${ }^{33}$ Roe Fremstedal, 'Kierkegaard's Double Movement of Faith and Kant's Moral Faith', Religious Studies 48 (2012): 212.

${ }^{34} \operatorname{SKS} 7,553$ / CUP, 610.

${ }^{35}$ SKS 7, 532 / CUP, 583-4.

${ }^{36}$ SKS 7, 526 / CUP, 578-9.
} 
relationship with that person in history-which actively enables her to relate both to God and the truth of revelation. ${ }^{37}$

What is disregarded in Fremstedal's statement is a recognition that conversion involves a person becoming 'a new creation' by sharing in 'a relationship not between man and man but between God and man'. ${ }^{38}$ In Christian conversion a person is reborn from above in response to the 'witness of the spirit within him' (Rom. 8:16). ${ }^{39}$ If the process of becoming a Christian simply involved the formation of a new set of presuppositions, then the only thing that would distinguish the Christian from the non-Christian would be a relatively different understanding. ${ }^{40}$ For Climacus, however, a person's commitment to her own notion of Christianity does not, in and of itself, enable a person to become eminently or decisively Christian. Any understanding of Christianity that a person comes up with in and of herself (for example, by reading the New Testament), does nothing more than bring that person into a relationship with her own (sinful and finite) thoughts about Christianity. For a person to become decisively Christian, a further or 'second' 'qualification' is required. That person needs to be given a faith that is sui generis: that is qualitatively distinct from the faith of the self-transformed religious believer (A). ${ }^{41}$ As Ingolf Dalferth notes, 'What has to occur is not merely a change in which a subject lives his or her life, but a change of subject. ${ }^{42}$

\footnotetext{
${ }^{37}$ As such, I find it unhelpful for Clare Carlisle to suggest that Kierkegaard 'seems unconcerned with the objective truth of God', even though she goes on to qualify that 'Kierkegaard's emphasis on transcendence distinguishes him from a non-realist interpretation of religious faith, since a transcendent God has to have power, has to be the source of actuality.' See Clare Carlisle, Kierkegaard's Philosophy of Becoming: Movements and Positions (Albany, NY: State University of New York Press, 2005), 135.

${ }^{38}$ SKS 27, 398 [Papir 365:12] / JP 1, 649:19.

${ }^{39}$ SKS 7, 553 / CUP, 610; see also SKS 23, 446 [NB20:99] / KJN 7, 454; SKS 4, 230-2 / PF, 21.

${ }^{40}$ With regard to this point Climacus remarks, 'The difference between the religious person and the person who does not religiously transform his existence becomes a humorous difference: that whereas the religious person utilizes his entire life in becoming aware of the relation to an eternal happiness and the other does not concern himself with it (but note that the religious person has the satisfaction within himself and, turned inward, is not busily engaged in meaningless complaints that others easily attain what he seeks with difficulty and with most extreme effort), they both, viewed eternally, go equally far.' (SKS 7, 530 / CUP, 581-2).

${ }^{41}$ Climacus writes, 'the eternal happiness to which the individual is assumed to relate himself with proper pathos is itself made dialectical' (SKS 7, 351 / CUP, 385). Under these circumstances, the dialectical mocks 'the gestures and big
} 
For Climacus, a person becomes decisively Christian by way of an existencecommunication (Existents-Meddelelse). ${ }^{43}$ As Fremstedal recognises, this involves the communication of a new passionate set of beliefs that are inextricably tied to human existence. ${ }^{44}$ For Climacus, these beliefs cannot be comprehended in advance (of their being appropriated to a person's existence) because, quite simply, if they have not transformed a person's existence then they have not been grasped for what they are. But what is unique to the Christian existence is that it rests upon an actual historical 'something' — an objective 'something' that transcends immanent human understanding ${ }^{45}$ - encountering a person in time and, in and through the moments of encounter, communicating an entirely new existence to her. ${ }^{46}$ Again, however, although we can find this kind of description of Christianity throughout Postscript, it is not until near the end, when Climacus clearly demarcates immanent religiousness (A) from paradoxical religiousness (B), that Christianity is unequivocally distinguished from all merely immanent forms of religiousness.

words' of Religiousness A and critiques the religious address that inspired Religiousness A. The religious address, he remarks, 'can very well be heard, but it cannot be done'; that is, it can proclaim what Christianity is but cannot actually bring a person to Christianity. (SKS 7, 505 / CUP, 556).

${ }^{42}$ Dalferth, 'Becoming a Christian according to the Postscript', 271.

${ }^{43}$ SKS 7, 349 / CUP, 383.

${ }^{44}$ SKS 7, 346 / CUP, 379-80.

${ }^{45}$ As Petrus Minor also tells us, 'It is different with every relation in the sphere of transcendence, and in turn it is different with the Christian concept of revelation. The essentially Christian exists before any Christian exists; it must exist in order for one to become a Christian. It contains the qualifications by which a test is made of whether someone has become a Christian; it maintains its objective continuance outside all believers, while it also is in the inwardness of the believer.' (SKS 15, 273 / Søren Kierkegaard, The Book on Adler, ed. and trans. by Howard V. and Edna H. Hong (Princeton, NJ: Princeton University Press, 1998), 117-8).

${ }^{46}$ SKS 7, 346 / CUP, 380; see also BA, 113. I think that H.R. Mackintosh is incorrect when, in his reading of Kierkegaard on the 'Christian Religion', he suggests that Kierkegaard (whom he equates with Climacus) 'persists in declaring that the inwardness of our own personal relationship to God positively depends on our blind acceptance of a Christological paradox, which is insoluble because intrinsically it is paradox and nothing else.' (H.R. Mackintosh, Types of Modern Theology - Schleiermacher to Barth (London: Nisbet and Co., 1937), 246; for a further helpful discussion of Mackintosh's reading of Kierkegaard, see David Gouwens, 'Hugh Ross Mackintosh: Kierkegaard as "a precursor of Karl Barth"' in Kierkegaard's Influence on Theology - Tome II: Anglophone and Scandinavian Protestant Theology, ed. Jon Stewart (Farnham: Ashgate, 2012), 85-104.). 
Religiousness A is the dialectic of inward deepening [Inderliggjørelsens Dialektik]; it is the relation to an eternal happiness that is not conditioned by a something but is the dialectical inward deepening of the relation, consequently conditioned only by the inward deepening, which is dialectical. On the other hand, Religiousness B, as it will be called from now on, or paradoxical religiousness, as it has been called, or the religiousness that has the dialectical in second place, makes conditions in such a way that the conditions are not dialectical concentrations of inward deepening but a definite something [bestemt noget] that qualifies the eternal happiness more specifically... ${ }^{47}$

With this qualification, readers are called to make sure that they have not confused the immanency of Religiousness A with Climacus's paradoxical vision of Christianity. By rereading Postscript with this passage in mind, it becomes clear that Climacus' portrayal of religious belief as an infinite interest in an eternal happiness does not decisively articulate what Christianity is. A decisively Christian faith centres around 'a definite something that qualifies the eternal happiness more specifically, ${ }^{48}$ Expressly, it hinges on the being and activity of God in time. Again, this is not to deny that Christianity is characterised by an infinite interest in one's eternal happiness, which Climacus does indeed affirm, ${ }^{49}$ but, rather, to affirm that Christianity does not find its centre in immanent human existence.

\footnotetext{
${ }^{47}$ SKS 7, 505-6 / CUP, 556; Petrus Minor refers to this section in The Book on Adler (SKS 15, 269 n. / BA, 113 n.). The fact that Climacus describes both forms of religiousness as involving a relationship to the eternal is possible because he (apparently) operates as an outside observer.

${ }^{48}$ SKS 7, 506 / CUP, 556.

${ }^{49}$ Such a description is evident throughout Postscript. (See, for example, SKS 7, 38, 58, 123, 205-6, 210, 298 / CUP, 33, 53, 130-1, 224, 231-2, 327). Both Religiousness A and Christianity involve a person passionately relating to another who she faithfully believes to be God, and both involve a person faithfully interpreting her relationship with God as her 'absolute telos' and her 'eternal happiness'.
} 
An area in which this qualification is particularly relevant is in Climacus' earlier discussion of the believer's faith in 'the actuality [Virkelighed] of another' — 'that the god [Guden] actually has existed [veret til]. ${ }^{50}$ When Climacus affirms here that it is the believer's infinite interest in the existence of the other that is decisive for faith, rather than the actual existence of the other (a definite something), he provides an account of religious belief that, without further qualification, cannot be regarded as decisively Christian. ${ }^{51}$ Unlike Religiousness A, the Religiousness B of Christianity requires an external other, God, to enter into time to upbuild a person in the Christian life. $^{52}$

The upbuilding element in the sphere of Religiousness A is that of immanence... In Religiousness B, the upbuilding is something outside the individual; the individual does not find the upbuilding by finding the relationship with God within himself but relates himself to something outside himself in order to find the upbuilding... That is why I have never called Religiousness A Christian or Christianity. ${ }^{53}$

\footnotetext{
${ }^{50}$ SKS 7, 295 / CUP, 324.

${ }^{51}$ SKS 7, 295-7 / CUP, 324-6. Earlier, Climacus notes, 'With regard to every actuality outside myself, it holds true that I can grasp it only in thinking. If I were actually to grasp it, I would have to be able to make myself into the other person, the one acting, to make the actuality alien to me into my own personal actuality, which is an impossibility.' (SKS 7, 293 / CUP, 321).

52 This point is also relevant when looking at the relationship with God in Eighteen Upbuilding Discourses. In these discourses Kierkegaard employs specifically Christian terminology. However, in these discourses the emphasis is generally put on humanity's immanent experience and beliefs rather than the actuality of an external God. For example, he states that the condition for knowing God is experiencing one's total need for God (SKS 5, 213-8 / Søren

Kierkegaard, Eighteen Upbuilding Discourses, ed. and trans. by Howard V. and Edna H. Hong (Princeton, NJ: Princeton University Press, 1990) (hereafter EUD), 321-6), and states that one comes to know God through 'deeper and more inward self-knowledge' (SKS 5, 270 / EUD 276). For this reason, Climacus did not consider these discourses to be specifically Christian in character. (SKS 7, 232-3 / CUP, 256-7).

${ }^{53}$ SKS 7, 510n. / CUP, 560-1n.
} 
Here, Climacus takes a sweeping blow at those who wish to see him as holding to a Romantic or even "existentialist" vision of Christianity. For Climacus, there is no Christian faith without the eternal God entering into time, in Christ, to deliver persons into a relationship with God precisely there in history. ${ }^{54}$ The Christian relationship with God rests wholly upon the actual God in time (who cannot be reduced to or subsumed within the sphere of immanent human thought) personally encountering individuals and thereby delivering them into a new life that is constituted by a two-sided relationship, mediated by the one who, precisely by being the eternal truth, constitutes the only way to that truth. ${ }^{55}$ It is as a consequence of this that the Christian is miraculously delivered from her natural, self-enclosed existence into a radically new form of existence. 'The existing person must have lost continuity with himself, must have become something else (not different from himself within himself), and now, by receiving the condition from the god, becomes a new creation. ${ }^{, 56}$ With this condition, which Climacus describes as faith, ${ }^{57}$ persons go beyond their own imaginations and relate to an eternal happiness that is grounded irremovably in a transcendent reality, in a way that is qualitatively different from all self-involved relationships.

\footnotetext{
${ }^{54}$ In light of the dynamic relationship between the person and God in Religiousness B, it is unhelpful for Michael Oleson to describe religiousness B as a "static state". (Michael Oleson, 'The Climacean Alphabet: Reflection on Religiousness A and B from the Perspective of the Edifying', in N.J. Cappelørn and H. Deuser, eds. Kierkegaard Studies Yearbook 2005 (Berlin and New York: Walter de Gruyter, 2005), 293).

${ }^{55}$ SKS 7, 505, 513, 518, 526n. / CUP, 556, 564, 570-1, 578n. Climacus describes this radical newness as a paradoxical newness, given that it involves a break with immanence and, therefore, a move that takes place against a person's immediate understanding. (SKS 7, 529 / CUP, 580-1).

${ }_{56}^{56}$ SKS 7, 524 / CUP, 576.

${ }^{57}$ SKS 4, 261 / PF, 59. In the thought experiment of Philosophical Fragments, Climacus associates the passion of faith with the 'condition' for understanding the truth that the god provides $(S K S 4,261 / P F, 59)$. The god who provides this condition is the servant god: 'god's presence is not incidental to his teaching but is essential. The presence of the god in human form - indeed, in the lowly form of a servant - is precisely the teaching, and the god himself must provide the condition; otherwise the learner is unable to understand anything.' ( $S K S$ 4, $258 / P F, 55)$. When we take this into account, we see that Climacus is of the view that faith arises in the moments in which the human learner passionately encounters and actively relates to the god in human form. When we consider that the object of faith is not merely an abstract paradox but the god-human, it becomes evident that a person's relationship to the truth is essentially an outward personal relationship-a relationship established in the external presence of the god in human form. In this relationship, a person's self-understanding steps aside and the servant god gives himself. And, in this relationship, faith arises as the "third something" that is constituted by the passionate relationship between the person and the god in human form. (SKS 4, 261 / PF, 59).
} 
It is precisely because the Christian truth is grounded in the reality of the god in time that Climacus refers to Christian existence as "paradoxical-religiousness": it is a category of existence that is grounded in a relationship with that which 'cannot be thought'. ${ }^{58}$ The 'something outside himself' to which the Christian relates himself is not merely relatively difficult to comprehendlike 'a relative paradox, which höchstens [at best] can be thought with difficulty' ${ }^{59}$ Rather, it is an absolute contradiction for human understanding precisely because it transcends the boundaries of immanent human thought. To clarify, the reality of the eternal God stands in radical (or 'absolute') contradiction to any perception of God or Christ that autonomous human reason can come up with through its own process of self-reflection. Whereas the former reality is the true God, the latter concept is one that can be found in any form of paganism. ${ }^{60}$

How, then, can a person relate to God? For Climacus and Kierkegaard, God interacts with a person spiritually: that is, with an entirely new spiritual activity that cannot be reduced to a person's own immanent spirituality. Through God's incarnate and spiritual presence, human subjects can come to relate positively to God. Under these circumstances, the person who becomes a Christian cannot look backward to try and work out speculatively how she came to relate herself to the eternal: for example, by reflecting on her upbringing in a Christian home. Such a move, would involve a person trying to reduce her conversion to an immanent progression, thereby setting aside her transformative encounter(s) with God in time. Instead, she must look forward in her journey with God in time, embracing the fact that, as a Christian, she now consciously participates in a

\footnotetext{
${ }_{58}^{58} \operatorname{SKS} 7,510$ / CUP, 561.

${ }^{59}$ SKS 7, 510 / CUP, 561.

${ }^{60}$ SKS 7, 508 / CUP, 559. Climacus writes, "The basis of the misunderstanding is that, despite the use of Christ's name etc., Christianity has been shoved back into the esthetic... where the incomprehensible is the relatively incomprehensible (relative either with regard to its not yet having been understood or to the need for a seer with an eagle eye to understand it), which in time has its explanation in something higher behind itself, rather than in Christianity's being an existence-communication that makes existing paradoxical, which is why it remains the paradox as long as there is existing and only eternity has the explanation." (SKS 7, 511-2 / CUP, 562).
} 
relationship with God. Again, she 'now moves forward in order to become eternal in time through the relation to the god in time. ${ }^{61}$

On this journey, God, who becomes one with us in history, interacts with a person as the 'by-nature eternal' one in and through whom it is possible for a person to devote her life to the eternal God. ${ }^{62}$ In this interrelationship, a person becomes distinguished by what Climacus describes as a 'pathos of separation': a pathos that distinguishes her from the universally human, and which could never be achieved by her own inward contemplation of the eternal reality that transcends her finite thought processes — what Climacus calls 'dialectical concentrations of inward deepening, ${ }^{63}$ What becomes unambiguously clear is that it is not a person's infinite interest in God's historical revelation that is central, but the passionate relationship into which God draws that person. This again means that any attempt to pursue the Christian truth by way of her own reflection and imagination - for example, through the introspection of Religiousness A—'will mistakenly revoke the paradox ${ }^{64}$ As soon as a person turns inward, into her own independent understanding, she diverts herself away from God and becomes entangled in her own pagan delusions. This person will,

...misunderstanding, understand Christianity as a possibility and forget that what is possible in the fantasy medium of possibility, possible in illusion, or what is possible in the fantastic medium of pure thinking... must, in the medium of actuality, become the absolute paradox...This is the paradoxical-religious, the sphere of faith. All of it can be believed - against the understanding. If anyone fancies that he understands

\footnotetext{
${ }^{61}$ SKS 7, 532 / CUP, 583-4.

${ }^{62}$ SKS 7, 526 / CUP, 578-9.

${ }^{63}$ SKS 7, 530, 505-8 / CUP, 582, 556-9.

${ }^{64}$ SKS 7, 529 / CUP, 580.
} 
this, he can be sure that he misunderstands it. The person who understands it directly (in contrast to understanding that it cannot be understood) will confuse Christianity with one or another analogy of paganism (delusion's analogy to factual actuality), or he will confuse it with the underlying possibility of all illusory analogies of paganism... Or he will confuse Christianity with something that has arisen in man's, that is, humanity's heart, confuse it with the idea of human nature and forget the qualitative difference that accentuates the absolutely different point of departure: what comes from God and what comes from man. ${ }^{65}$

In this passage, Climacus is not suggesting that Christianity dismisses human understanding altogether. He is happy to acknowledge that the Christian should maintain a respect for universal human reasoning: a person 'can use it in all other circumstances, use it in his association with others' ${ }^{66}$ Furthermore, he does not think that a person can become a Christian without having at least some understanding of what Christianity is about: such as 'a believer's report' of Jesus Christ as the object of faith. ${ }^{67}$ Also, he does not think that a person can live the Christian life without some understanding of what it means to be a follower of Jesus Christ. Indeed, Kierkegaard's writings are devoted to articulating what it means to exist as a Christian.

In what sense, then, does Christianity go 'against the understanding'? ${ }^{68}$ For Climacus, the truth of Christianity cannot be properly recognised in advance of becoming a Christian—and, as

\footnotetext{
${ }^{65}$ SKS 7, 528 / CUP, 579-80.

${ }^{66}$ SKS 7, 516 / CUP, 567-8. It is thus an overstatement for Cornelio Fabro to suggest that, for Kierkegaard, 'the GodMan is the "absolute paradox" which destroys reason.' (Cornelio Fabro, 'Faith and Reason in Kierkegaard's Dialectic', trans. J.B. Mondin in A Kierkegaard Critique: An international selection of essays interpreting Kierkegaard, eds. Howard A. Johnson and Niels Thulstrup (Chicago, IL: Henry Regnery Company, 1962), 171-2).

${ }^{67} S K S$ 4, 291, $301 / P F, 93,104$.

${ }^{68} \operatorname{SKS} 7,528$ / CUP, 579-80.
} 
such, he cannot recognise the truth of Christianity for himself. What this means is that becoming a Christian is not a possibility, therefore, for which a person can prepare herself mentally. Any empirical, imaginative and/or speculative attempts to come to terms with Christianity for oneself can only ever come up with a false imitation — a "Christianity" that has been chopped and changed according to the Procrustean bed of a particular person's finite understanding. Christianity stands in radical contradiction to any supposition that the understanding could potentially come up with for itself, for example, by examining Scripture and trying to construct or imagine the God to whom it testifies.

Why can a person's understanding not come up with Christianity for itself? Why can a person not prepare herself to become a Christian by simply reading her Bible? What is it about Christianity that makes it so absolutely different from any other life-view? The answer to these questions is that the Christian life is an enacted response to an unanticipatable event of actual encounter with God - an encounter that is transformative and, moreover, reconstitutive of who one is. ${ }^{69}$ As such, Christian conversion rests, as we have seen, upon dynamics that radically transcend the workings of a person's immanent cognitive faculties_-indeed, it rests upon dynamics that transcend the inner workings of the created order per se. Christian existence rests upon divine acts of grace: free acts of God ('what comes from God') that cannot be foreseen, predicted, summoned, earned or emulated by the human understanding ('what comes from man'). ${ }^{70}$ The faith of the Christian arises in response to an encounter with God who, for Kierkegaard, 'can only show himself

\footnotetext{
${ }^{69}$ This raises the question as to how the Christian can recognise that she has actually encountered God and not simply a figment of her imagination? For Kierkegaard, a person cannot know this with immediate certainty. She, therefore, needs to believe and trust with faith that God is actively at work in her life, enabling her to be a Christian. As Kierkegaard writes on his own Christian faith, 'With a sword hanging over my head, I am ordered to say whether or not I am a Christian. My answer would be: I trust to God that I am a Christian; I believe that out of grace he will accept me as a Christian... The question of whether I am a Christian (and thus for every individual, whether he is a Christian) is entirely a God-relationship.' (SKS 16, 117 [BN], PV, 135; see also Keith Lane, 'The Uncertainty of the Confessing Christian' in Kierkegaard and the Concept of Religious Authorship (Tübingen: Mohr Siebeck, 2010), 139-45).

${ }^{70}$ SKS 7, 528 / CUP, 580.
} 
to a human being in a miracle; that is, as soon as he sees God, he sees a miracle. ${ }^{, 71}$ Therefore, there is no do-it-yourself Christianity. Indeed, for Climacus, the do-it-yourself attitude of the creature's understanding itself needs to be 'crucified' to make way for a faith that sees God as awakening any Christian understanding within us. ${ }^{72}$

That being said, this does not mean that the miracle of God encountering persons goes against human understanding per se. Rather, it deepens, transforms and thereby satisfies the desire for understanding in ways that are more profound than we could ever envisage in advance.

When God draws a person to himself, he reconciles her mind such that it corresponds to the truth that God is in himself. In and through this, the Christian relates to God with a faith that does not repose in her immediate grasp of things but, counterintuitively, finds understanding in the 'absolute paradox' of God's being with us in time. ${ }^{73}$ In this way, her immediate understanding is displaced in order to make way for Jesus Christ who alone makes Christianity a possibility. Accordingly, her understanding does not default to its more natural responses. It does not, for example, (1) try to explain away the absolute paradox; (2) try to go around the absolute paradox to know God behind the absolute paradox; or (3) take offense and deny the absolute paradox. Instead, a person's understanding humbly recognises the priority of the eternal God and his self-revelation in time: the priority that the absolute paradox has over a person's immediate understanding. By so doing, the human understanding conforms to the reality of God rather than the other way round. The

\footnotetext{
${ }^{71}$ SKS 18, 226 [JJ:270] / KJN 2, 207. The advantage of turning to Fragments from Kierkegaard's unpublished journals and papers is that they offer us a multi-faceted and detailed account of how Kierkegaard understands what it means to be a Christian from within his own Christian life. They help us to see-both on this issue and on other issues-what is going on in Kierkegaard's mind behind his more formally published writings.

${ }_{72}$ SKS 7, 465-6 / CUP, 513-5.

${ }^{73}$ To clarify, the Christian faith should not be understood as a way of knowing in which God grants persons the ability to understand and master Christianity for themselves; that is, by giving them some cognitive condition to know the truth of Christianity self-evidently. Rather, Christian existence is maintained by an ongoing relationship with God. That is, by participating in a relationship that is itself maintained through the momentary interactions between divine and human agency - through a tapestry of divine communication and human reception, divine enabling and human awakening.
} 
Christian confesses that it is not her own categories of thought that are responsible for delivering her or sustaining her in her new relationship to the truth, but, rather, it is the particular object of her faith, God in time.$^{74}$ With this confession, the Christian stands and embraces the 'absolute wonder' that 'answers to the truly divine, which understanding has not come upon. ${ }^{, 75}$

Kierkegaard himself later emphasises this point with his more distinctively Christian voice. Drawing on Gal. 2:20, he affirms that when the Christian shares in fellowship with the incarnate God, she does not relate to Jesus Christ as "one who is dead and departed but one who is living. ${ }^{, 76}$ In fellowship with Jesus Christ, the Christian 'really lives in and together with him' ${ }^{77}$ Jesus Christ 'is to be and become your life, so that you do not live to yourself, no longer live yourself, but Christ lives in you. ${ }^{78}$

In the process of this awakening a person becomes conscious of her self-understanding's alienation from God. In response to a divine act of revelation, she becomes conscious of her sin. As we shall now consider, this is very different from becoming conscious of one's guilt. It requires a person to turn away from her inward dwelling by being drawn into a new life in relationship with God: a life that does not find fulfilment in individual self-perfection before God but rather in a humble life of relationship with God—a life before God.

\section{Sin-Consciousness}

\footnotetext{
${ }^{74}$ SKS 24, 459-60 [NB25:35] / JP 2, 1908.

${ }^{75}$ SKS 18, 210-11 [JJ:218] / KJN 2, 193 (emphasis original).

${ }^{76}$ SKS 10, 274 / Søren Kierkegaard, Christian Discourses, ed. and trans. Howard V. and Edna H. Hong (Princeton, NJ: Princeton University Press, 1997) (hereafter $C D), 261$ (emphasis mine).

${ }^{77}$ SKS 10, 274 / CD, 261.

${ }^{78}$ SKS 10, 274 / CD, 261; Gal. 2:20.
} 
It is not possible to grasp the full implications of Kierkegaard's Christian realism without appreciating a further key element in Climacus's argument. The enemy of Christian realism is sinsin, indeed, which all too easily takes the form of guilt-consciousness. If a person is to become a Christian, she must become conscious of her alienation from God, that is, of her sin. What Climacus and Kierkegaard see with such clarity is that this is profoundly different from a consciousness of guilt.

How does Climacus interpret guilt-consciousness? In his account of immanent religiousness, Climacus notes that the finite religious believer is unable to resign herself absolutely to God. Moreover, she cannot even properly acknowledge her absolute dependence upon God: she will always fail to become 'absolutely captive in the absolute conception of God' ${ }^{79}$ She is, therefore, doomed to failure. Aware of this failure, she withdraws to the decisive expression of religiousness: Guilt-consciousness. With guilt-consciousness, a person construes her failure to live out the religious life in terms of a "disrelation" (Misforholdet) to her eternal happiness, which is able to inspire a life of continual repentance. ${ }^{80}$ By judging herself as guilty in her failure to relate to God, the religious believer expresses that she is relating herself to an eternal happiness (albeit negatively), and recognizes herself as a person who stands before God (albeit absolutely distantly) ${ }^{81}$ This does not mean that her guilt-consciousness brings her any closer to God—only God can bring her closer to God. But it does mean that the religious believer holds an attitude that is proper to her life of failure before God.

\footnotetext{
${ }^{79}$ SKS 7, 438 / CUP, 483.

${ }^{80}$ SKS 7, 483 / CUP, 531 (emphasis mine). Along with C. Stephen Evans and David Law, I am using the Swenson and Lowrie translation here of Misforholdet as 'disrelationship' rather than the Hongs' translation, 'misrelation'. The reason for this is that 'disrelationship' stresses the negativity that Climacus wants to underscore, in contrast to 'misrelation', which places more emphasis on the faultiness of the relationship. (See Søren Kierkegaard, Concluding Unscientific Postscript to Philosophical Fragments, ed. and trans. David Swenson and Walter Lowrie (Princeton, NJ: Princeton University Press, 1941), 473).

${ }^{81} \operatorname{SKS} 7,483$ / CUP, 531-32.
} 
Guilt-consciousness, therefore, turns a person inward to dwell on her error. Sinconsciousness, however, turns a person outward to God such that her error is dealt with. Unlike guilt-consciousness, sin-consciousness does not serve to compound an individual's sense of existential failure, and the attendant anxiety and despair. Rather, it alerts a person to the fact that she exists in a manner that is incommensurate with the way in which God created her to exist. It then leads a person to turn away from her proud autonomous existence by being drawn into a new life in relationship with God: a life that does not find fulfilment in individual self-perfection before God but rather in a humble life of relationship with God, in which a person becomes perfect.

How does a person become conscious of her sin if not by way of an inward selfcontemplation? ${ }^{82}$ What is required is an external 'power' to awaken her. 'This power is the god in time. ${ }^{, 83}$ It is only by becoming conscious of God in the power of his historical presence that a person can receive a consciousness of $\sin { }^{84} \operatorname{Sin}$-consciousness and Christ-consciousness are, therefore, interdependent states that can only be constitutive of the Christian's faith when they are held together. ${ }^{85}$ On the one hand, a person cannot truly know what it means to be a sinner unless she knows what it means to be a sinner before God-who-reveals-himself-in-Jesus-Christ. On the other hand, she cannot truly know Jesus Christ unless she has the sin-conscious faith to access this truth the consciousness that, apart from Christ, she exists in untruth. Although the pseudonymous

\footnotetext{
${ }^{82}$ For Climacus, the individual is 'unable to gain the consciousness of sin by himself, which is the case with guiltconsciousness, because in guilt-consciousness the subject's self-identity is preserved, and guilt-consciousness is a change of the subject within the subject himself. The consciousness of sin, however, is a change of the subject himself, which shows that outside the individual there must be the power that makes clear to him that he has become a person other than he was by coming into existence, that he has become a sinner.' (SKS 7, 532 / CUP, 584).

${ }^{83} \operatorname{SKS} 7,532$ / CUP, 584.

${ }^{84} \operatorname{SKS} 7,532$ / CUP, 584. It is because sin-consciousness arises by way of a power that comes from beyond a person's universal understanding - making him 'aware of himself in the difference from the universally human' - that Climacus describes sin-consciousness as 'the expression for the paradoxical transformation of existence.' (SKS 7, 531-2 / CUP, 583-84).

${ }^{85}$ Kierkegaard also views sin-consciousness and love for God as interdependent states. He notes that 'when a person does not comprehend what a great sinner he is, he cannot love God; and when he does not love God (through the proclamation to him of how much God loves him), he cannot comprehend how great a sinner he is.' (SKS 27, 489 [Papir 410]/ JP 2, 1216).
} 
Climacus alludes to this interconnection, it is in Kierkegaard's own writing that we find a much more substantive and theologically robust account of this relationship. By turning to Kierkegaard, and particularly to his later writings, we are able to go beyond the relatively skeletal and abstract account provided by the non-Christian Climacus.

For Kierkegaard, sin-consciousness is essentially Christ-centred. 'The Consciousness of Sin Binds to [Christ] ${ }^{86}$ With Luther, he believes that there is something wrong with the Christian who attempts to deal with her sin by drawing inward (becoming homo incurvatus in se), burdening herself with a sense of guilt and despair. This move, he believes, is how the (Christ-less) pagan responds to $\sin$ —'he descends into melancholia, broods ruminatively on his guilt, and sin perhaps gains more and more power over him, so that in desperation he sinks ever more deeply. ${ }^{87}$ The Christian, however, is called to deal with his sin-consciousness by sinking deeper into a humble respect for the eternal God, thereby developing a deeper awareness that it is only God, in Christ, who is his redeemer. That is, the Christian deals with his sin by turning to God and taking refuge in his grace, with a consciousness of his sin as forgiven sin. 'A [person] reposes in the forgiveness of sins when the thought of God no longer reminds him of the sin, but of the fact that it is forgiven, so that what is past is not a recollection of how much he offended, but of how much he has been forgiven. ${ }^{88}$ At the centre of Kierkegaard's doctrine of sin, we find, yet again, the reality of the God of grace who personally encounters us in history.

...in faith we receive something that is not given and can never be deduced from the preceding consciousness, for this was the consciousness of sin and the other is

\footnotetext{
${ }^{86} \operatorname{SKS} 23,344$ [NB19:22] / KJN 7, 350; SKS 23, 439 [NB20:81] / KJN 7, 447.

${ }^{87}$ SKS 23, 83 [NB15:118] / KJN 7, 81.

${ }^{88}$ SKS 20, 187 [NB2:116] / KJN 4, 185; see also SKS 21, 23 [NB6:26] / KJN 5, 22.
} 
assurance of the forgiveness of sins, but this assurance does not result in the same way that knowledge arises with internal consistency out of doubt... [and] someone who conceived it in this way does not have the preceding position (consciousness of $\sin$ ), but it is a free act. ${ }^{89}$ Nor is the consciousness of sin an arbitrary [human] act, like doubt is; it is an objective act, because the consciousness of God is immanent within the consciousness of $\sin$. In addition, the consciousness of the forgiveness of sins is linked to an external event, [Christ]'s whole appearance, which is indeed not [external] in the sense of foreign to us, of no concern to us, but [external] as historical. $^{90}$

With these words, Kierkegaard dismisses any notion that sin-consciousness is a legal move that a person needs to make in advance in order to participate in a relationship with God. That is, although he views sin-consciousness as a subjective requirement for the Christian faith, he sees it as one that can only arise through God's relating to us in Christ. Apart from God, a person can neither know nor love God, and, therefore, cannot become conscious of the sin that opposes God's love. ${ }^{91}$

\section{Repentance}

The reason that it is so easy to make the mistake of thinking that individuals are independently responsible for becoming conscious of sin is because it involves a transformation of the individual

\footnotetext{
${ }^{89}$ It is not entirely clear what Kierkegaard is suggesting here. This sentence does, however, seem to make some sense if he is describing the "assurance of forgiveness" as "a free act" because its emergence is not constrained by the limits of one's immanent reason, but is free for anyone to develop in response to an encounter with Christ.

${ }^{90}$ SKS 19, 185-86 [Not5:23] / KJN 3, 181-82.

${ }^{91}$ SKS 27, 489 [Papir 410] / JP 2, 1216.
} 
in response to a reality that cannot be directly observed. Another essential facet of the Christian faith that is easily misconstrued in this way is repentance. The church has often reduced repentance to a legal step that a person needs to make (in advance) in order to participate in a loving relationship with God - as opposed to a response that a person makes as she is given to become aware of God's love and thus participate in it. This vision of repentance has arisen by deconstructing the interpersonal dynamic between God and humanity—by examining the activity of the two sides of this relationship separately - in order to develop a step-by-step guide on how to become a Christian. Contrary to this kind of systematic approach, grounded in what Calvin referred to as legal repentance, Kierkegaard views repentance as a possibility that can only come about when a person encounters God and, in his presence, humbly acknowledges her need for forgivenesswhat Calvin referred to as evangelical repentance. ${ }^{92}$ This is not a routine that a person contemplates in advance, like the repentant speech that the prodigal son prepares for his father in advance of the father's embrace. Rather, it is the silent sorrow that overcomes a person when she stands face to face with God and realizes that she has nothing to contribute, not even an act of repentance. ${ }^{93}$ It is thus in silent repentance that a person humbly turns to God with a longing for relationship. And when she does so, repentance is 'the easiest and most natural relation to God' ${ }^{94}$ As Kierkegaard's pseudonym, Judge William writes, ${ }^{95}$

\footnotetext{
${ }^{92}$ See John Calvin, Institutes of the Christian Religion, ed. John McNeil, trans. Ford Lewis Battles (Philadelphia, PA: Westminster Press, 1960), 3.3.1-3.3.4. For further discussion of the notion of 'evangelical repentance', see my article: 'John Calvin and James Torrance's Evangelical Vision of Repentance', Participatio, Supp. Vol. 3 (2014): 126-47.

${ }^{93}$ Kierkegaard writes in a journal entry, 'We ordinary human beings do not have a direct or spontaneous Godrelationship...we always need grace beforehand, because even the most sincere beginning is always imperfect compared to the demand of the ideal - consequently it is like a new sin.' (SKS 25, 223 [NB28:12] / JP 2, 1493).

${ }^{94}$ SKS 24, 180 [NB22:147] / JP 2, 1419.

${ }^{95}$ It might seem strange to turn to Judge William for a Christian account of repentance, given that one of the points this essay is advancing is that Kierkegaard's earlier pseudonymous writings do not offer a decisively Christian account of religious existence. This is particularly the case for Judge William who is committed to, as Joel Rasmussen notes, a 'bourgeois Christianity of culture'. (Joel Rasmussen, Between Irony and Witness: Kierkegaard's Poetics of Faith, Hope, and Love (New York: T\&T Clark, 2005), 42). Nonetheless, this does not mean that such earlier writings were not able to advance statements or propositions that were true to Kierkegaard's account of what Christianity is. They were simply
} 
But there is a love with which I love God, and this love has only one expression in language - it is "repentance." If I do not love him in this way, then I do not love him absolutely, for I love out of necessity. As soon as I love freely and love God, then I repent. And if there were no other basis for repentance as the expression of my love of God, it is this- that he has loved me first. ${ }^{96}$

Although Kierkegaard does not locate the heart of Christian repentance in individual speech or action, he does acknowledge that genuine repentance will entail sorrow over one's sin-sorrow for a life lived, and to some extent still lived, in offense against God. Furthermore, because he holds human beings personally responsible for sin, he affirms that Christian repentance demands not only the 'agony of sin-consciousness; but also the "anguish of a contrite conscience", which, to an extent, means a consciousness of guilt ${ }^{97} \mathrm{He}$ further describes repentance as the burdening concern that is required by the gospel's invitation to "Come here to me, all who labor and are burdened, and I will give you rest" (Matt. 11:28). ${ }^{98}$ He does not suggest, however, that the individual is to dwell despairingly on her guilt. As a Lutheran, he merely affirms that honest repentance will be characterized by a heartfelt sorrow — by an attitude with which a person turns to God for rest. The penitent who experiences anguish and sorrow, he says, 'properly understands what it is to pray for rest for the soul, rest in the one and only thought in which there is rest for a penitent, that there is

missing a decisive appreciation for the unique way in which God relates to us in history, thereby enabling a Christian life. It is for this reason, in particular, that these works fail to recognise what it means to be decisively Christian.

${ }^{96}$ SKS 3, 208 / Kierkegaard, Either/Or, Part 2, ed. and trans. by Howard V. and Edna H. Hong (Princeton, NJ: Princeton University Press, 1987), 216. Following this passage, Judge William goes on to stress the importance of a person freely acknowledging his guilt, but sees this choice as one that arises through participation in a loving relationship with God, rather than a prerequisite for this relationship.

${ }^{97}$ SKS 10, 269 / CD, 264.

${ }^{98}$ SKS 10, 269 / CD, 264-65. 
forgiveness; rest in the one and only declaration that can reassure a penitent, that he is forgiven; rest on the one and only ground that can support a penitent'. ${ }^{99}$

Again, however, there is no extent to which the penitent's sorrow can be seen to counteract her sin. The penitent Christian cannot, for Kierkegaard, be perceived as paying for her sin with the anguish of a contrite conscience. One could even go so far as to say that any repentant activity on the individual's part will be so inadequate (as a human act) that it will itself require repentance. This is again because, apart from Christ, all human activity falls infinitely short of the glory of God. Objectively speaking, Christian repentance depends wholly upon Christ and what he has achieved for the world in the atonement. Subjectively speaking, repentance transpires by becoming conscious of one's need for grace in and through the gracious presence of God. ${ }^{100}$

\section{Conclusion}

The Christian can never, for Kierkegaard, be certain that she is decisively Christian because her understanding cannot capture the reality of the divine subject who determines the actuality of her Christian faith. ${ }^{101}$ This is because, while Christian belief and understanding are crucial for the active Christian existence, they do not constitute the Christian relationship with God. For the Christian, it is the interpersonal relationship with God that decisively distinguishes the Christian's faith from all immanent forms of religiousness. For Kierkegaard,

\footnotetext{
${ }^{99}$ SKS 10, 270 / CD, 265.

${ }^{100}$ See $S K S$ 10, 73 / CD, 64; SKS 20, 69 / KJN 4, 67-68. It is slightly misleading for Louis Dupré to describe a person's need for God as his 'intervention in the process of redemption.' As he elaborates, 'Christ will provide the rest, but this one element man must supply in full sincerity: the constantly renewed need for God. The only means for achieving this is an increasingly interiorized consciousness of sin.' (Louis Dupré, Kierkegaard as Theologian (London: Sheed and Ward, 1964), 91 (emphasis mine)).

${ }^{101}$ See $S K S$ 22, 127-8 [NB11:204] / KJN 6, 124-25.
} 
So it is with the relation to [Christ that a person] tests himself as to whether [Christ] is everything to him, and he says, I am betting everything on it. But I cannot get an immediate certainty about my relation to Christ. Whether I have faith is something I can't get immediate certainty about—for to believe is precisely this dialectical hovering, which is constantly in fear and trembling yet never despairs; faith is precisely this infinite self-concern that keeps one alert in risking everything, this selfconcern about whether one really has faith—and behold, this very self-concern is faith. ${ }^{102}$

For Climacus, the Christian is called to believe that she has faith. She is called to believe that God — who transcends what she is naturally able to work out for herself — is miraculously transforming her existence. If it turns out that there never was a God who was present to her, working in her life, then the Christian's existence was never anything more than an immanent form of religiousness. However, the Christian does not believe this. She believes that her faith is an expression of her relationship with God in time, with Jesus Christ, who governs her and shapes her in ways that transcend what she can ascertain. And, for Kierkegaard, she believes this because God

\footnotetext{
${ }^{102}$ SKS 20, 382 [NB5:30] / KJN 4, 382. The emphasis on 'infinite self-concern' in this passage could be seen to undermine Kierkegaard's emphasis on the loving nature of the relationship with God. However, as Climacus explains in Fragments, 'self-love lies at the basis of love' $(S K S 4,253 / P F, 48)$. When a person falls in love with another, she initially does so out of self-love or self-concern. For Climacus, love requires this initial self-concern to draw a person towards an other - a self-concern he associates with erotic love. However, as a person becomes passionately interested in the other, she becomes shaped by the other. And, in instances of genuine love, she becomes a self who is overcome by an orientation towards the other: a self who is concerned about putting the other before herself. In the process of this becoming, the moments of passion that enable a person to fall in love are characterized by both a self-concern and a concern for the other. As such, with the passion of erotic love (with which a person finds self-fulfilment in her love for the other), we find there to be a mutual understanding between a person's concern for the other and her concern for herself. What we see here is definitive of Climacus' understanding of passion: it is an internal quality that enables a self to become drawn towards and shaped by the external realities - or, in particular, drawn to love and become shaped by another subject.
} 
is with her enabling her to hold fast to this truth. To the outside observer, defined by her own feeling of independence, this existence makes no sense. The Christian's faith looks to be a product of her imagination running wild, of parental indoctrination, of misplaced hope; it cannot be recognized as more than a self-perpetuating delusion. However, for the Christian, who consciously shares in a relationship with God, her faith makes sense of her life. It does so because she has encountered God and been awakened to the fact that she lives before the reality of God who, inconceivably, has established kinship with us in time. ${ }^{103}$

\footnotetext{
${ }^{103}$ I am extremely grateful to Murray Rae, Jeremy Begbie, Jim Fodor, and the anonymous reviewers for their helpful feedback on an earlier version of this paper.
} 